\title{
CRUSTAL STRUCTURES FROM THE EASTERN ALGERIAN BASIN TO THE IONIAN OCEAN - CENTRAL MEDITERRANEAN
}

R. CATALANO', A. FRANCHINO², S. MERLINI² and A. SULLI'

Palermo University, Dipartimento di Geologia e Geodesia,

Via Archirafi 26, 90123 Palermo, Italy

Eni SpA Agip Division

\section{Introduction}

Results from the interpretation of deep seismic lines (CROP Italian Deep Crust Project) provide the first, continuous, 900-km-long crustal geologic transect crossing the Central Mediterranean from the Algerian Sea to the Ionian Sea (Fig. 1). The geoseismic section (Fig. 2) reveals crustal and Moho reflections to a depth of about $30 \mathrm{~km}$ and elucidates the crustal architecture and processes associated with the opening of the Oligo-Miocene Algerian-Provencal basin, the Tertiary mountain building of the Alpidic chain and the Mesozoic continental rifting to oceanic spreading of Malta-Iblean margin-Ionian abyssal plain.

The unmigrated crustal lines were calibrated by using geological and geophysical data from boreholes (Fig. 2) and supplemented dense grid of higher resolution but shallower AGIP reflection seismic lines. Previously published magnetic, heat flow, gravity and bathymetry, as well as seismic refraction data (ESP, DSS, EGT and WARR) were used to constrain, at a regional scale, the crustal structures interpreted from the seismic reflection lines.

\section{Observations and results}

The eastern side of the 3000-m-deep Algerian Sea (Fig. 2) images the Moho discontinuity at a depth of $7.5 \mathrm{~s} /$ TWT $(12 \mathrm{~km})$ and the crystalline basement at $6.0 \mathrm{~s} /$ TWT $(6 \mathrm{~km})$. The estimated crustal thickness of $9 \mathrm{~km}$ suggests its oceanic nature. West-dipping normal faults step down towards the Algerian basin documenting the occurrence of a related eastern continental margin. The Moho reflector changes abruptly to a layered high-amplitude reflector band beneath the Sardinia Channel (Figs. 1, 2). We locate the Moho at the base $(7.5 \mathrm{~s} /$ TWT $)$ of the layered band which is interpreted as a stretched lower continental crust. From the Sardinia Channel to the Comaglia Terrace, the Moho deepens to about $9 \mathrm{~s} / \mathrm{TWT}$ occurring at the base of the layered lower continental crust. Two major crustal reflecting units including crystalline and sedimentary rocks (thick skinned folded belt) are separated by a westward-dipping regional listric thrust plane (Sardinian Thrust Front). They form the upper crust in the Cornaglia Terrace-Elimi Ridge sector (Fig. 2). The hanging wall and the footwall of the thrust plane correlate to the well known Sardinian and Kabilian units respectively. The Kabilian wedge overrides the Maghrebian-Apenninic crustal segment at the Elimi Ridge along a detachment plane which ramps south-eastwards forming the Drepano Thrust Front. The Moho as deep as $10 \mathrm{~s} / \mathrm{TWT}$ in the Elimi Ridge, rises to $8.5 \mathrm{~s} / \mathrm{TWT}$ towards the offshore Sciacca; the top of the crystalline basement (African basement) is located at a depth of about 14-15 km (Fig. 2). The overlying stack of westward dipping thrust sheets (Egadi Thrust Front, Fig. 3) appears decoupled from the undeformed crust (thin skinned folded belt). West-dipping carbonate embricate fans culminate at the Adventure Bank and offshore Sciacca. Here the crystalline basement rises to $5 \mathrm{~s} / \mathrm{TWT}$ $(12 \mathrm{~km})$ and the crystalline crust is about $15 \mathrm{~km}$ thick. The offshore Agrigento shows the frontal sector of the Sicilian chain consisting of a 3000-m-thick accretionary wedge (Gela Nappe) sandwiched in between Plio-Pleistocene strata of the Iblean autochthonous (Fig: 2). The crystalline basement is here located at a depth of $12 \mathrm{~km}$. Crustal reflections constrained by seismic refraction contribute in revealing the structure of a well developed passive continental margin facing the ocean (Fig. 2).

The continental margin extends from the Iblean-Pelagian shelf to the Malta-Western Ionian slope and rise; it has been described as the conjugated margin of the Apulian swell in the other side of the Ionian Sea. The ocean develops southeastward in the Eastern Ionian abyssal plain (Fig. 2). The ancient morphology of the margin was deformed, along the Malta Escarpment, by an eastward-facing post-Early 
Tortonian, mostly extensional fault system. The continental margin crust becomes progressively thinner eastwards, as revealed by the rising of the Moho depth to about $19 \mathrm{~km}$ in Western Ionian. Both early Mesozoic block faulting of the sedimentary cover and the occurrence of large mounds interpreted as igneous bodies emplaced along the early continental margin (Fig. 2) support the transitional nature of the crust flooring the Malta slope-Western Ionian sector. The igneous intrusions generating strong magnetic anomalies lead to the hypothesis of a magmatic underplating of the thinned continental crust in a mantledominated plume passive margin model. An abrupt change of the seismic characteristics depicts the continent-ocean boundary (Figs. 2, 4). The 4000-m-deep eastern Ionian abyssal plain (Fig. 2) is characterised by a crystalline crust, $1.5-2 \mathrm{~s} / \mathrm{TWT}(6-8 \mathrm{~km})$ thick which develops between 8.8 and 7.2 s/TWT. The crust consists of a layered reflector (oceanic layer 3 ) overlain by a seismically transparent and unstratified band (oceanic layer 2) topped by chaotic or hummocky reflectors (oceanic crystalline basement, $\mathrm{Ob}$ ). A flat-lying, high frequency, seismic body covering the $\mathrm{Ob}$ reflector is interpreted as the sedimentary overburden. The Moho reflection marks the base of the highly reflectivity package at 8.8-9.2 s/TWT $(15-17 \mathrm{~km})$ as defined by ESP seismic refraction data. Several arguments support the oceanic nature of the crust flooring the Ionian abyssal plain, even if an interpretation of the layered reflectors as a lower crust of an extremely thinned continental crust intruded by upper mantle materials cannot be rejected. The age of the initial oceanic spreading is still unclear, without borehole stratigraphy; either a pre-Late Jurassic or Cretaceous (?) age can be inferred when we attempt to correlate the strata resting on the continental margin to the oldest sediments onlapping the assumed oceanic crystalline basement.

\section{Main references}

CASERO P., CITA M.B., CROCE M. and DE MICHELI A., 1984. Tentativo di interpretazione evolutiva della scarpata di Malta basata su dati geologici e geofisici. Mem. Soc. Geol. It., 27, 233-253.

CATALANO R., D'ARGENIO B. and TORELLI L.,1989. From Sardinia Channel to Sicily Strait. A geologic section based on seismic and field data. In: The Lithosphere in Italy, Acc. Naz. Dei Lincei, Atti dei Congressi Lincei, 80: 109-127.

CATALANO R., FRANCHINO A., MERLINI S. and SULLI A. (2000). A crustal section from the North Algerian basin to the Ionian ocean (Central Mediterranean). Mem. Soc. Geol. It., in press.

CATALANO R., DOGLIONI C. and MERLINI S. (1999). On the Mesozoic Ionian basin. Geophysical Journal International, in press.

CERNOBORI L., HIRN A., MCBRIDE J. H., NICOLICH R., PETRONIO L., ROMANELLI M. and STREAMERS/PROFILES Working Groups, 1996. Crustal image of the Ionian basin and its Calabrian margins. Tectonophysics, 264: 175-189.

DELLA VEDOVA B., PELLIS G. and PINNA E., 1989. Studio geofisico dell'area di transizione tra il Mar Pelagico e la Piana Abissale dello Jonio. Atti $8^{\circ}$ Conv. Ann. GNGTS, 543-558

DE VOOGD B., TRUFFERT C., CHAMOT-ROOKE N., HUCHON P., LALLEMANT S. and LE PICHON X., 1992. Two-ship deep seismic soundings in the basins of the Eastern Mediterranean Sea (Pasiphae cruise). Geophys. J. Int., 109, 536-552.

FINETTI I., 1982. Structure, stratigraphy and evolution of the Central Mediterranean. Boll. Geofis. Teor. Appl., 24, 247-315.

NICOLICH R., 1989. Crustal structures from seismic studies in the frame of the European Geotraverse (southern segment) and Crop Projects. In: The lithosphere in Italy edited by A. Boriani, M. Bonafede, G.B. Piccardo and G.B. Vai, Accad. Naz. Lincei, 80, 41-61.

SCARASCIA S., LOZEJ A. and CASSINIS R., 1994. Crustal structures of the Ligurian, Thyrrenian and Ionian seas and adjacent onshore areas interpreted from wide-angle seismic profiles, Boll. Geof. Teor. Appl., 36, 141-144, 519.

Figure captions

Fig. 1. Location map of the study area.

Fig. 2

Fig. 3. The seismic profile shows the characters and geometry of the carbonate Maghrebian-Apenninic thrust sheets culminating in the Egadi Isl. region.

Fig. 4. The seismic profile shows sharp transition between the stretched thinned continental crust and interpreted oceanic crust on the SE. S: faulted Early Mesozoic sediments lying on continental basement; Vm: igneous mound; M: Moho; LOC: layered oceanic crust; Ob: oceanic basement; R: Mesozoic-Pleistocene basinal deposits; Me: Messinian horizon (deformed on the NW sector ?). 


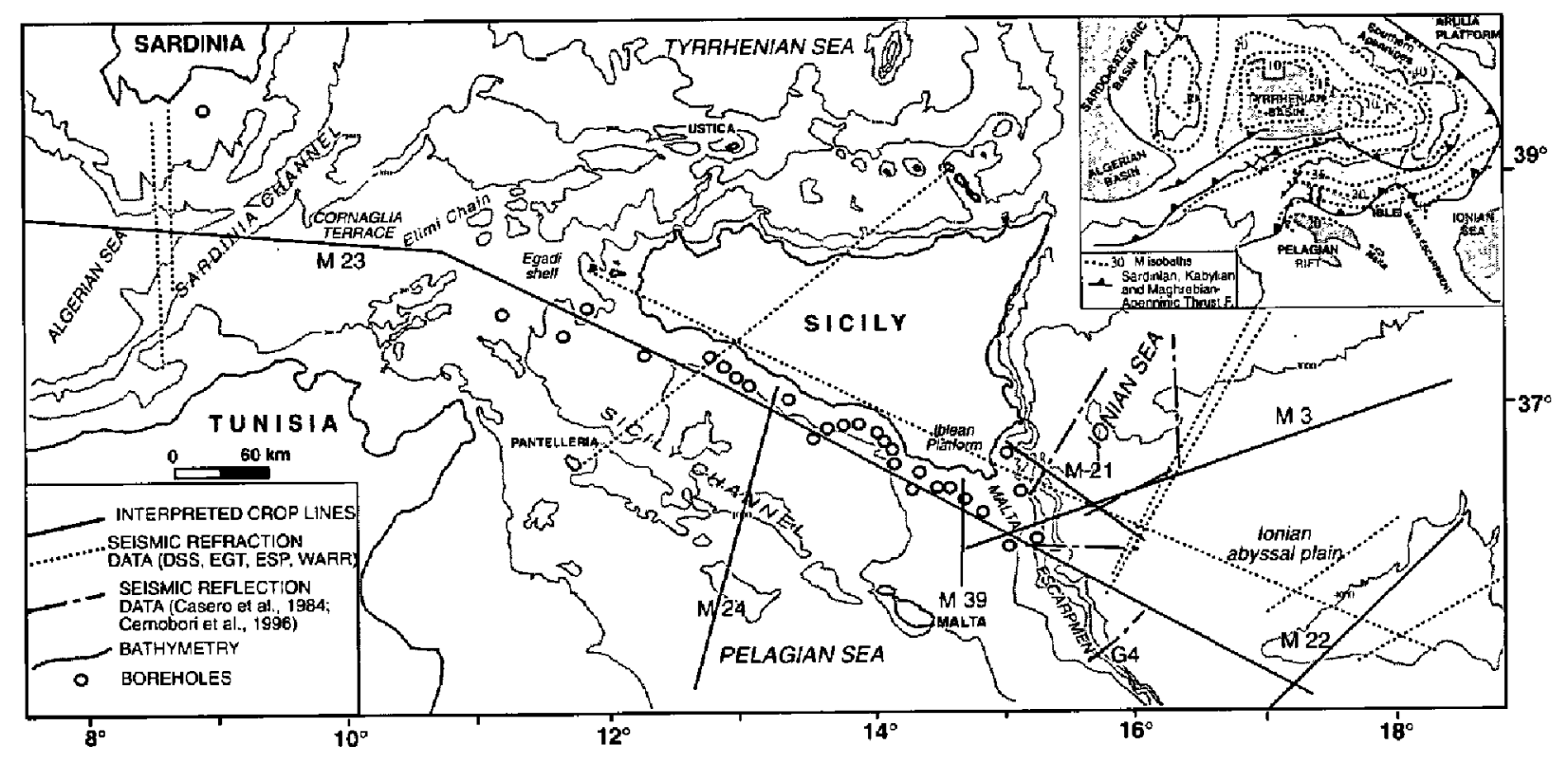




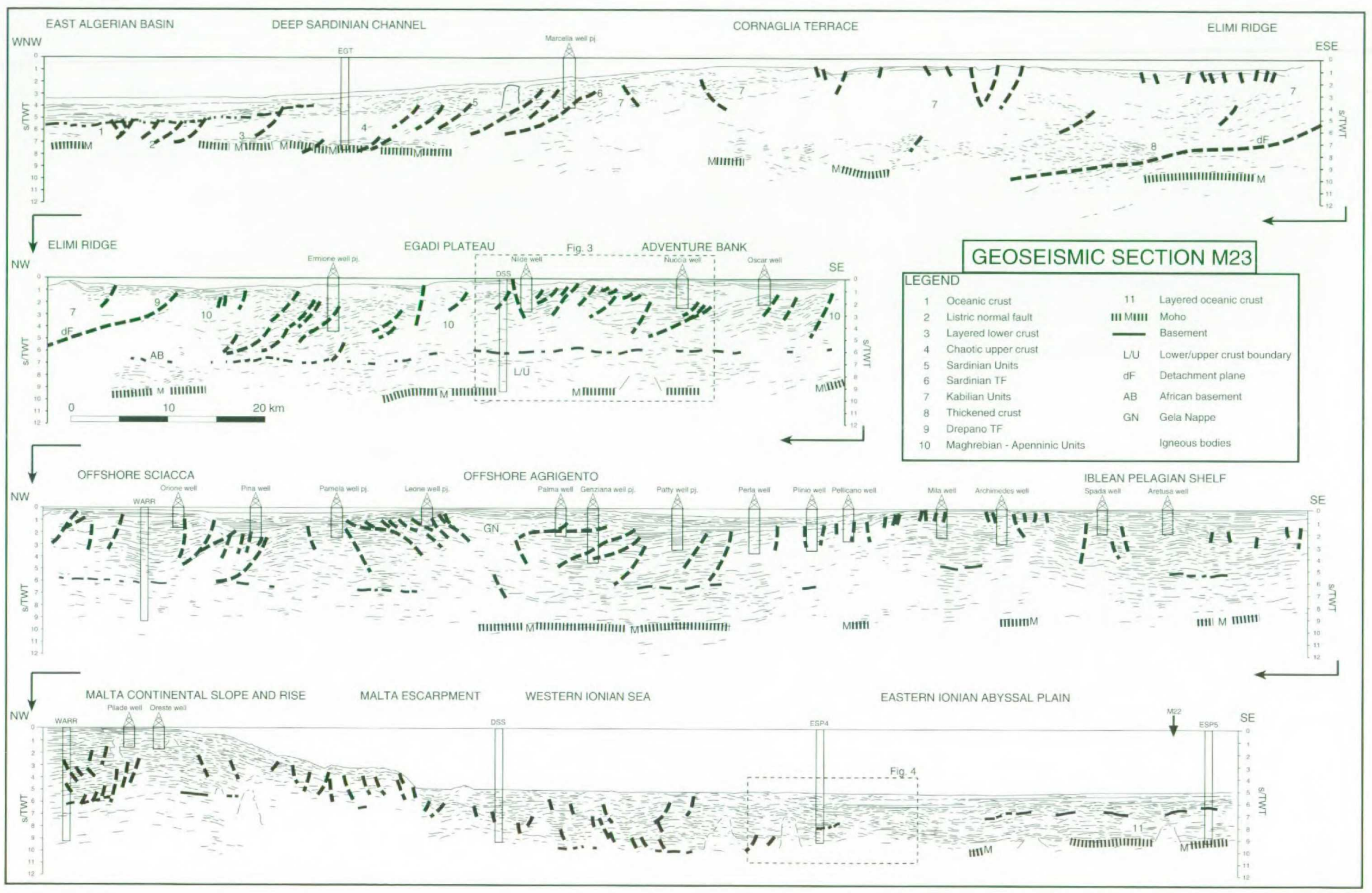




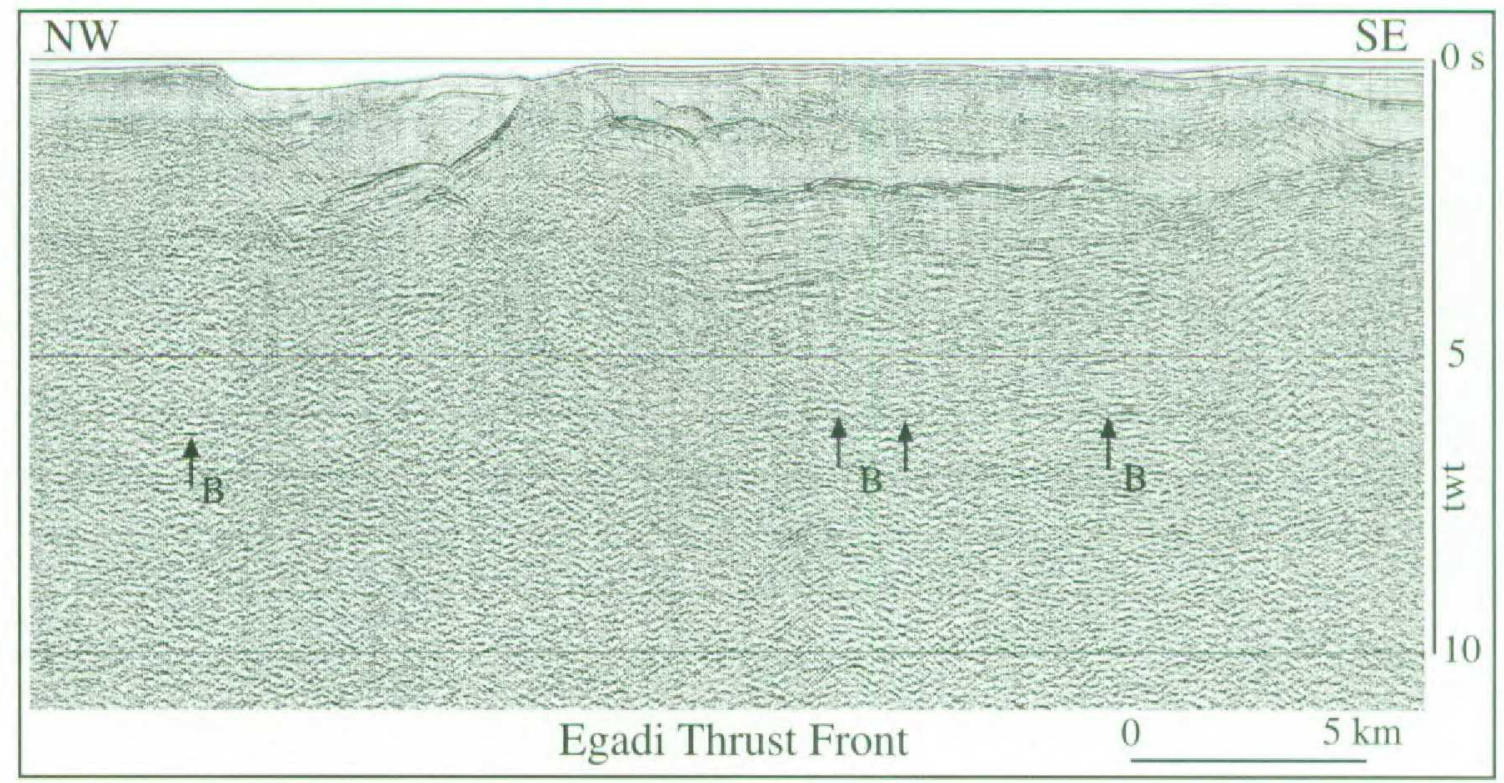




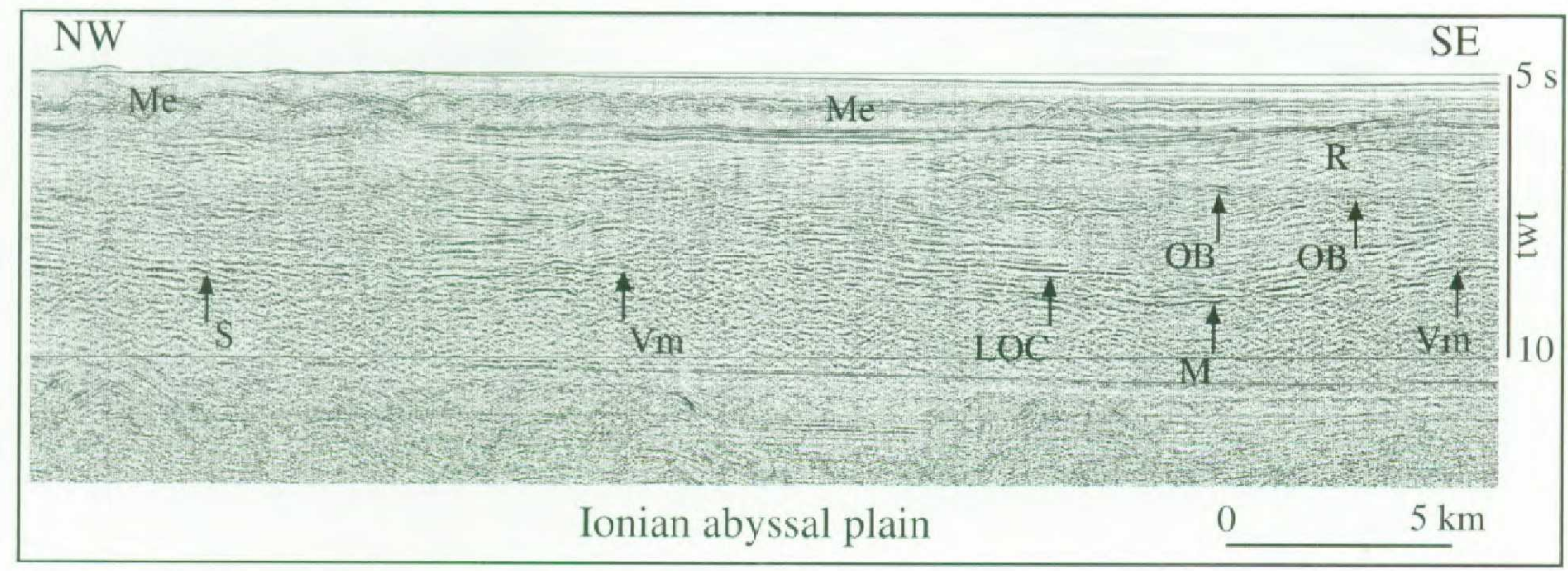

